$$
\text { DOE/EH- }-97000 / 57
$$

SOUTHWESTERN POWER ADMINISTRATION

SITE ENVIRONMENTAL REPORT

FOR CALENDAR YEAR 1995

\author{
TULSA, OKLAHOMA \\ WILLIAMS CENTER TOWER I
}

JANUARY 1, 1995 - DECEMBER 31, 1995

SOUTHWESTERN POWER ADMINISTRATION

P. 0. BOX 1619

TULSA, OKLAHOMA 74103

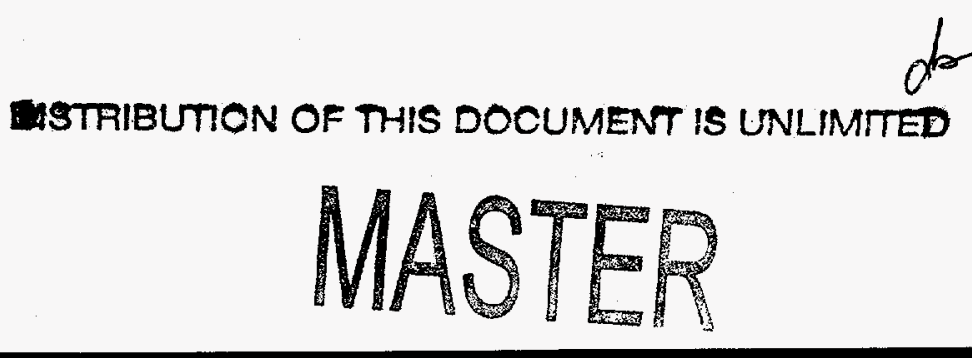




\section{DISCLAIMER}

Portions of this document may be illegible in electronic image products. Images are produced from the best available original document. 


\section{DISCLAIMER}

This report was prepared as an account of work sponsored by an agency of the United States Government. Neither the United States Government nor any agency thereof, nor any of their employees, makes any warranty, express or implied, or assumes any legal liability or responsibility for the accuracy, completeness, or usefulness of any information, apparatus, product, or process disclosed, or represents that its use would not infringe privately owned rights. Reference herein to any specific commercial product, process, or service by trade name, trademark, manufacturer, or otherwise does not necessarily constitute or imply its endorsement, recommendation, or favoring by the United States Government or any agency thereof. The views and opinions of authors expressed herein do not necessarily state or reflect those of the United States Government or any agency thereof. 


\title{
SOUTHWESTERN POWER ADMINISTRATION SITE ENVIRONMENTAL REPORT FOR CALENDAR YEAR 1995
}

\author{
TULSA, OKLAHOMA \\ WILLIAMS CENTER TOWER I \\ JANUARY 1, 1995 - DECEMBER 31, 1995
}

SOUTHWESTERN POWER ADMINISTRATION

P. 0. BOX 1619

TULSA, OKLAHOMA 74103 
TABLE OF CONTENTS

EXECUTIVE SUMMARY . . . . . . . 1

INTRODUCTION . . . . . . . . . . 2

COMPLIANCE SUMMARY . . . . . . 3

ENVIRONMENTAL PROGRAM INFORMATION . . 6

ENVIRONMENTAL RADIOLOGICAL PROGRAM . . 7 INFORMATION

ENVIRONMENTAL NON-RADIOLOGICAL . . . . 7 PROGRAM INFORMATION

EXECUTIVE ORDER 12856 COMPLIANCE. . . 8

GROUNDWATER PROTECTION . . . . . . 8

QUALITY ASSURANCE . . . . . . . . . 9

PERFORMANCE INDICATORS . . . . . 9 


\section{EXECUTIVE SUMMARY}

DURING CY 95, SOUTHWESTERN WAS NOT INVOLVED IN ANY PROGRAMS THAT HAD A DIRECT EFFECT ON THE ENVIRONMENT, INVOLVING ENDANGERED SPECIES, PROTECTION OF WETLANDS, OR INCREASED ELECTROMAGNETIC RADIATION. SOUTHWESTERN CONTINUED TO FUNCTION THROUGHOUT THE YEAR IN AN OPERATIONS AND MAINTENANCE POSTURE WITH MINOR SUBSTATION PROJECTS. SOUTHWESTERN RECEIVED TWO DOE AUDITS, MARCH 1991 AND 1993. SOUTHWESTERN HAS WORKED DILIGENTLY ON THE DOE APPROVED ACTION PLAN AND HAS COMPLETED THE REQUIRED EFFORT. THE AUDITS PROVIDED THE SECRETARY, DOE HEADQUARTERS, AND SOUTHWESTERN AN INDICATION OF THE STATUS OF SOUTHWESTERN MANAGEMENT'S EFFECTIVENESS IN DISCHARGING ITS DUTIES IN AN ENVIRONMENTALLY RESPONSIBLE MANNER. SENIOR MANAGEMENT AT SOUTHWESTERN HAS TAKEN ACTIONS TO INCREASE ENVIRONMENTAL AWARENESS THROUGHOUT THE ORGANIZATION WHICH IS EVIDENCED BY THE CREATION OF THE ENVIRONMENTAL, SAFETY, HEALTH, AND SECURITY OFFICE, AND THE ESTABLISHMENT OF ENVIRONMENTAL AND SAFETY APPOINTED REPRESENTATIVES AT VARIOUS FIELD LOCATIONS. 


\section{INTRODUCTION}

THE SOUTHWESTERN POWER ADMINISTRATION (SOUTHWESTERN) IS A POWER MARKETING AGENCY OF THE DOE CREATED IN 1943. SOUTHWESTERN MARKETS HYDROPOWER THAT IS PRODUCED BY 23 FEDERAL DAMS OPERATED BY THE U. S. ARMY CORPS OF ENGINEERS IN OKLAHOMA, ARKANSAS, MISSOURI, AND TEXAS. MARKETING THIS HYDROPOWER AND ENSURING ITS RELIABLE DELIVERY CONSTITUTE THE CORE OF SOUTHWESTERN'S PROGRAM. SOUTHWESTERN MAINTAINS 1,380 MILES OF HIGH-VOLTAGE TRANSMISSION LINES AND ASSOCIATED SUBSTATIONS. SUPPORT FOR OPERATION AND MAINTENANCE OF THIS SYSTEM IS PROVIDED BY AN AREA-WIDE MICROWAVE COMMUNICATIONS SYSTEM. THIS SYSTEM INTERFACES WITH THE U. S. ARMY CORPS OF ENGINEERS' MICROWAVE SYSTEM AND INCLUDES TELEMETERING. SUPERVISORY CONTROL AND DATA ACQUISITION (SCADA), MOBILE RADIO BASE STATION CONTROL, COMPUTER DATA TRANSMISSION, AND TELEPHONE COMMUNICATIONS. THESE FACILITIES, PLUS THE CORPS' GENERATING FACILITIES, MAKE UP THE SOUTHWESTERN FEDERAL POWER SYSTEM. THE AGENCY IS HEADQUARTERED IN TULSA, OKLAHOMA WITH ENGINEERING AND MAINTENANCE FACILITIES LOCATED IN SPRINGFIELD, MISSOURI; JONESBORO, ARKANSAS; GORE AND TUPELO, OKLAHOMA. THE ADMINISTRATIVE OFFICES IN TULSA PROVIDE A COMPLETE RANGE OF SUPPORT FUNCTIONS INCLUDING LEGAL, FINANCIAL, PROCUREMENT, AUTOMATIC DATA PROCESSING, ENGINEERING, AND POWER MARKETING. SOUTHWESTERN'S LEGISLATIVE MANDATE IS SECTION 5 OF THE FLOOD CONTROL ACT OF 1944. THIS LAW REQUIRES SOUTHWESTERN TO GIVF PREFERENCE IN SALES TO PUBLIC BODIES AND COOPERATIVES AND TO ACHIEVE WIDESPREAD USE OF THE POWER. 
(January 1, - December 31, 1995)

\section{COMPLIANCE STATUS}

Southwestern Power Administration (Southwestern) conducted its operations and maintenance during the calendar year with no identified environmental problems or issues. The on-going program to remove a 71 testable PCB contaminated equipment (50-499 ppm) is continuing. Most of Southwestern's non-testable (assumed 50-499 ppm PCB) equipment is electrical bushings. They will be utilized for their useful life or until replaced by gas breakers. As the bushings (OCBS) are changed out, they are properly disposed of as PCB contaminated equipment.

The following major environmental statutes and Executive Orders are discussed:

-- Comprehensive Environmental Response, Compensation, Liability Act (CERCLA)

Southwestern currently has no facilities listed on or under consideration for the CERCLA; the National Priorities List (NPL); or the Federal Facilities Compliance Docket.

-- Resource Conservation and Recovery Act (RCRA)

Southwestern has developed a Waste Management Program and a Waste Minimization Plan.

-- Federal Facilities Compliance Act (FFCA)

Southwestern is in compliance with the FFCA. Southwestern doesn't generate any mixed waste or have any TSD Facilities.

-- Superfund Amendments and Reauthorization Act (SARA)

Southwestern has notified applicable State and Local officials of sites containing chemicals in amounts exceeding the threshold reporting requirements.

-- National Environmental Policy Act (NEPA)

Southwestern is in compliance with NEPA requirements. Southwestern has been given authority for environmental assessment, findings of no significant impact, and categorical exclusion approval. 
- Clean Air Act (CAA)

Southwestern does not have any radioactive sources; therefore, does not perform any radiation or radionuclide monitoring.

-- Clean Water Act (CWA) / Safe Drinking Water Act (SDWA)

Southwestern utilizes city water at its manned facilities. At six unmanned sites, there is one potable well and five non-potable wells; these are tested by the appropriate state. Southwestern has closed two of these wells and is considering the need for the remaining wells.

-- Toxic Substances Control Act (TSCA)

Southwestern has an on-going program to dispose of equipment containing PCB-contaminated $0 i 1$. Southwestern currently has no testable pieces of equipment which contain 500 ppm or greater PCB concentrate.

Southwestern has a plan in place to dispose of a11 testable PCBcontaminated equipment containing 50-499 ppm PCB. Southwestern strives to dispose of any PCB-contaminated equipment within 30 days of removal from service and declared excess to Southwestern's needs.

-- Federal Insecticide, Fungicide, and Rodenticide Act (FIFRA)

Southwestern has completed an environmental assessment concerning the utilization of a selected vegetation control method utilizing a combination of mechanical/manual and herbicide control. This program would be utilized on sections of the rights-of-way. An environmental assessment is being completed for utilization of a selected vegetation control method at the 24 substations and some radio microwave sites.

All herbicide spraying wi 17 be accomplished by certified personnel. No restricted herbicides wil1 be utilized.

- Endangered Species Act (ESA)

Southwestern has no major construction projects; therefore, there is minimal involvement with this Act.

-- National Historic Preservation Act (NHPA)

Southwestern has no major construction projects; therefore, there is minimal involvement wit'i this Act. 
-- Executive Order 11988. "Floodplain Management"

Southwestern has no major construction projects; therefore, there is minimal involvement with this Act.

-- Executive Order 11990, "Protection of Wetlands"

Southwestern has no major construction projects; therefore, there is minimal involvement with this Act.

Southwestern personne] review changes to the above Acts and Orders but have minimal opportunity to utilize any of them.

\section{OTHER MAJOR ENVIRONMENTAL ISSUES AND ACTIONS}

Southwestern did not have any significant environmental issues unresolved at the end of CY 95.

Southwestern received two environmental audits by the Department. One in December, 1991, and the last in March, 1993. The DOE approved action plan corrective action is complete. Since the audits. Southwestern Senior Management has established positions at the field locations with position descriptions requiring a percentage of their time devoted to environmental functions. An environmental activities management field position has also been established with the majority of this position being dedicated to environmental functions. Additionally. Southwestern has been very proactive in the Total Quality Management (TQM) arena since 1989. Southwestern has in place al1 the required environmental orders and has ensured that the appropriate personnel have received the required training. Southwestern conducted training on a need-to-know basis for all field personnel who might be involved with any items of equipment that are covered under the environmental statutes.

\section{SUMMARY OF PERMITS}

Gore, OKlahoma Maintenance Facility - EPA Identification Number (PCB) Tupelo, OK lahoma Maintenance Facility - EPA Identification Number (PCB) Springfield, Missouri Maintenance Facility - EPA Identification Number(PCB) Jonesboro, Arkansas Maintenance Facility - EPA Identification Number (PCB) 
ENVIRONMENTAL PROGRAM INFORMATION

\section{GENERAL COMPLIANCE INFORMATION}

\section{COMPLIANCE SUMMARY}

\section{CURRENT ISSUES AND ACTIONS}

Southwestern's major involvement in the environmental field is with PCB electrical equipment. Southwestern established a goal to change-out and dispose of all testable PCB equipment over 500 ppm PCB by FY 90. This goal was achieved. Southwestern has had no spil1s and/or releases. Southwestern has accomplished minor substation construction to include a new Operations and Maintenance facility, completed in CY 95.

Southwestern did not initiate nor complete any environmental impact statements but did initiate one environmental assessments (EA) during $\mathrm{CY}$ 1994 (Vegetation Control Along Transmission Line Rights-of-Way). The EA was completed during CY 95 . Environmental staff has trained the field personnel in the techniques of conducting self-assessments. The field wi17 conduct self-assessments at one site in each geographic location during $\mathrm{CY}$ 96 and the environmental staff will perform an appraisal in each area. Awareness training has been conducted in environmental areas to include pollution prevention and waste minimization. 
ENVIRONMENTAL PERMITS

See Summary of Permits (Above)

RADIOLOGICAL INFORMATION

Southwestern has no radiological involvement.

NON-RADIOLOGICAL INFORMATION

NPDES - Southwestern conducted a study to determine if additional involvement is required in this area. The study indicated that no NPDES permits were required at Southwestern facilities.

SARA TITLE III - The substances of primary concern at Southwestern facilities include sulfuric acid, present in lead-acid batteries used for back-up power: sulfur hexafluoride. present in gas circuit breakers; and polychlorinated biphenyl (PCBS), potentially present in small quantities in hermetically-sealed, oil-filled bushings and other electrical equipment. Sulfur Hexafluoride is not considered a hazardous chemical, therefore no TPQ is listed and there are currently no reporting requirements. PCBs are not considered to be an extremely hazardous substance, however, PCBs are listed as a hazardous substance. Southwestern does not have sufficient equipment containing PCB to qualify for the amounts required for reporting. Southwestern is in the process of changing out all of the "wet cell" batteries with "gel batteries". When this conversion is completed, none of Southwestern's facilities will contain sufficient sulfuric acid to qualify for reporting requirements. 


\section{EXECUTIVE ORDER 12856 COMPLIANCE -}

$\underline{1995}$

EPCRA 302-303: Planning Notification N/R

EPCRA 304: EHS Release Notification N/R

EPCRA 311-312: MSDS/Chemical Inventory N/R

EPCRA 313: TRI Reporting N/R

GROUNDWATER PROTECTION - Southwestern conducted a study to determine if additional involvement is required in this area. The study which included ranking the substations utilizing CERCLA criteria as applicable to Southwestern, testing and sampling the soil and groundwater at the substation that had the highest total from the ranking system and analyzing the data, Southwestern determined that additiona 1 groundwater monitoring is not required

\footnotetext{
HAZARDOUS MATERIAL SPILLS - Southwestern has had no spil1 of reportable quantity of hazardous materials.
}

TOXIC CHEMICAL INVENTORY - Southwestern utilizes batteries for emergency backup power at various locations (substations and radio stations). In some instances, the quantity of sulfuric acid present exceeds the threshold limits. 
QUALITY ASSURANCE - Southwestern has developed a Quality Assurance Program. The program provides Headquarters and field units the capability to ensure that quality assurance is considered and applied in all areas.

- Southwestern has developed an Environmenta] Performance Indicators Trending System Standard. The standard provides Headquarters and field units the capability to identify indicators which would provide an indication of potential environmental problems and/or deteriorating environmental conditions; and to identify indicators which would monitor the affects of improving environmental performance. CY 96 will provide the first opportunity for the standard to be evaluated.

Performance Indicators selected for utilization are: 1) Findings from environmental self-assessment/ appraisal program; 2) environmental $\$$ spent versus $\$$ budgeted;

3) gallons of oil remaining; and 4) environmental checklist findings. 